\title{
Integrative medicine for relief of nausea and vomiting in the treatment of colorectal cancer using oxaliplatin-based chemotherapy: A systematic review and meta-analysis
}

Chen, Meng; May, Brian; Zhou, Iris Wenyu; Zhang, Anthony Lin; Xue, Charlie Changli

https://researchrepository.rmit.edu.au/esploro/outputs/9921860369901341/filesAndLinks?institution=61RMIT_INST\&index=null

Chen, M., May, B., Zhou, I. W., Zhang, A. L., \& Xue, C. C. (2016). Integrative medicine for relief of nausea and vomiting in the treatment of colorectal cancer using oxaliplatin-based chemotherapy: A systematic review and meta-analysis. Phytotherapy Research, 30(5), 741-753. https://doi.org/10.1002/ptr.5586 Document Version: Accepted Manuscript 
Thank you for downloading this document from the RMIT Research Repository.

The RMIT Research Repository is an open access database showcasing the research outputs of RMIT University researchers.

RMIT Research Repository: http://researchbank.rmit.edu.au/

\section{Citation:}

Chen, M, May, B, Zhou, I, Zhang, A and Xue, C 2016, 'Integrative medicine for relief of nausea and vomiting in the treatment of colorectal cancer using oxaliplatin-based chemotherapy: A systematic review and meta-analysis', Phytotherapy Research, vol. 30, no. 5, pp. 741-753.

See this record in the RMIT Research Repository at:

https://researchbank.rmit.edu.au/view/rmit:37001

Version: Accepted Manuscript

Copyright Statement:

(C) 2016 John Wiley and Sons, Ltd.

Link to Published Version:

https://dx.doi.org/10.1002/ptr.5586 


\section{Integrative medicine for relief of nausea and vomiting in the treatment of colorectal cancer using oxaliplatin-based chemotherapy: a systematic review and meta-analysis}

\begin{tabular}{|r|l|}
\hline Journal: & Phytotherapy Research \\
\hline Manuscript ID & Draft \\
\hline Wiley - Manuscript type: & Review \\
\hline Date Submitted by the Author: & n/a \\
\hline Complete List of Authors: & $\begin{array}{l}\text { Chen, Menghua; RMIT University, Health Sciences } \\
\text { May, Brian; RMIT University, Health Sciences; } \\
\text { Zhou, Wenyu; RMIT University, School of Health Sciences and Health } \\
\text { Innovations Research Institute (HIRi) } \\
\text { Xue, Charlie; School of Health Sciences RMIT University, Division of } \\
\text { Chinese Medicine } \\
\text { Zhang, Anthony; RMIT University, Health Sciences }\end{array}$ \\
\hline Keyword: & $\begin{array}{l}\text { natural products, nausea, vomiting, colorectal cancer, oxaliplatin, } \\
\text { integrative medicine }\end{array}$ \\
\hline & \multicolumn{2}{|l}{} \\
\hline
\end{tabular}

\section{SCHOLARONE ${ }^{\text {m }}$}

Manuscripts 
Integrative medicine for relief of nausea and vomiting in the treatment of colorectal cancer using oxaliplatin-based chemotherapy: a systematic review and meta-analysis

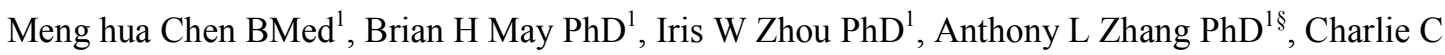
Xue $\mathrm{PhD}^{1,2}$.

${ }^{1}$ The China-Australia International Research Centre for Chinese Medicine, School of Health Sciences, RMIT University, Bundoora, VIC 3083, Australia

${ }^{2}$ Guangdong Provincial Academy of Chinese Medical Sciences \& Guangdong Provincial Hospital of Chinese Medicine, Guangzhou, China

${ }^{\S}$ Corresponding author:

Dr Anthony L Zhang

The China-Australia International Research Centre for Chinese Medicine

School of Health Sciences RMIT University, PO Box 71, Bundoora, Vic. 3083, Australia

Tel: +613 99257758, Fax: +61399257178

E-mail: tony.zhang@rmit.edu.au

Email addresses of other authors (note: mailing address is as above for all authors):

Meng hua Chen BMed: PhD candidate, RMITUniversity, aussway@yahoo.com.au

Brian H May PhD: Clinical Research Fellow, RMITUniversity, brian.may@rmit.edu.au

Iris W Zhou PhD: Research Fellow, RMITUniversity, wenyu.zhou@rmit.edu.au

Charlie C Xue PhD: Head of School of Health Sciences, RMITUniversity, charlie.xue@rmit.edu.au

Review article: 4,302 words (body text), 2 tables, 2 figures, 2 supplementary

Short title: Traditional medicines for nausea and vomiting in CRC

Funding support: 1. The project is partially supported by an International Research Grant from the Guangdong Provincial Academy of Chinese Medical Sciences, Guangdong Province, China. 2. Meng hua Chen is supported by an Australian Postgraduate Award at RMIT University, Australia.

Conflict of interest disclosure: The authors have no financial interests or other conflicts of interest related to the material in this manuscript. This research has not been published and is not under submission, in whole or in part, to other journals. All authors have contributed to the paper. 
Ethics statement: Ethics approval was not required for this study

\title{
Key words
}

Systematic review, natural products, nausea, vomiting, colorectal cancer, oxaliplatin, integrative medicine, traditional medicine

\begin{abstract}
The management of chemotherapy-induced nausea and vomiting (CINV) remains an issue in the treatment of colorectal cancer using oxaliplatin based regimens. Certain traditional plant-based medicines (TMs) have histories of use for nausea and vomiting and have integrated with conventional therapies for CINV. To assess the effectiveness of integrative management of CINV, meta-analysis was conducted of 27 randomised controlled studies (1,843 participants) published from 2005 to 2013. The oxaliplatin plus TM groups showed significantly reduced CINV (RR $0.65[0.59,0.71], \mathrm{I}^{2}=28 \%$ ) compared to oxaliplatin controls, with or without the addition of conventional anti-emetics. Further sensitivity analyses based on the ingredients of the TMs identified six plants (Atractylodes macrocephala, Poria cocos, Coix lacryma-jobi, Astragalus membranaceus, Glycyrrhiza uralensis, Panax ginseng) that were associated with significant reductions in CINV without important heterogeneity. Experimental studies of these six plants have reported inhibitory effects on nausea and vomiting (or its animal equivalent), regulation of gastrointestinal motility, gastro-protective effects, and antioxidant actions which may at least partially explain the effects identified in the meta-analyses of the clinical trial results. These plants warrant further clinical research as additions to chemotherapy regimens in patients whose CINV is not sufficiently well-controlled by conventional therapies.
\end{abstract}


2

3

4

5

6

7

8

9

10

\section{Abbreviations}

5-FU: 5-Fluorouracil

AEs: Adverse Events

CINV: Chemotherapy-induced Nausea and Vomiting

CNKI: China Academic Journals

CQVIP: Chinese Science and Technology Journals

CRC: Colorectal Cancer

FOLFOX: 5-Fluorouracil (5-FU) plus Leucovorin (LV) combined with Oxaliplatin

G-CSF: Granulocyte colony-stimulating factor

KPS: Karnofsky Performance Status

LV: Leucovorin

NCI-CTC: National Cancer Institute Common Toxicity Criteria

RCT: Randomized Controlled Trial

RD: Risk Difference

RR: Risk Ratio

TMs: Traditional Medicines

WHO: World Health Organisation 


\section{Introduction}

Chemotherapy-induced nausea and vomiting (CINV) is a common adverse event in cancer treatment. Risk factors for CINV following chemotherapy include type of chemotherapeutic drug, patient's age less than 50, female, history of low prior chronic alcohol intake, and history of previous chemotherapy-induced emesis. Over seventy percent of patients receiving oxaliplatin regimens experience CINV (Navari, 2009). CINV tends to get worse as the number of treatment cycles increases. This significantly reduces the quality of life of patients, can result in poor compliance with their chemotherapy schedule and can lead to deterioration of physical and mental status (Lohr, 2008).

The mechanisms of CINV are complex. CINV can be initiated by enterochomaffin cells in the gastrointestinal tract releasing serotonin (5-HT) in response to damage of gastrointestinal epithelium and activation of the chemoreceptor trigger zone which detects potential toxins. Activation of vagal afferent fibres stimulates the vomiting center in the medulla, which in turn sends impulses via efferent fibres to activate the vomiting response. Antiemetic drugs act by blocking neuronal pathways involved at various stages in the emetic response, mainly via antagonism of 5-hydroxytryptamine (5$\mathrm{HT}_{3}$ ) receptors, dopamine receptors, neurokinin-1(NK-1) and/or acetylcholine, corticosteroid, histamine, cannabinoid, and/or opiate receptors (Lohr, 2008; Navari, 2009).

Oxaliplatin regimens used in colorectal cancer (CRC) are considered to have moderate emetic risk and the preventative use of $5-\mathrm{HT}_{3}$ antagonists combined with dexamethasone is recommended, with the additional use of NK-1 antagonists in selected patients (NCCN, 2012). Despite the introduction of these effective anti-emetic agents, CINV remains a significant issue for people undergoing chemotherapy (Navari, 2009).

A number of traditional medicines (TMs) have been used to alleviate nausea and vomiting. Ginger (Zingiber officinale Roscoe) has been used for nausea in a number of countries and evidence from animal studies suggests anti-CINV effects (Handiadka et al., 2012a). However, a systematic review of seven randomised controlled trials (RCTs) of ginger in CINV management in various cancers found inconsistent results between studies (Marx et al., 2013). Other plants that have been reported to alleviate CINV in animal models include Panax ginseng C. A. Mey., Panax quinquefolius L., Panax notoginseng (Burk.)F. H. Chen, Scutellaria baicalensis Georgi, Ganoderma lucidum (Fr.)Karst., Mint oil (Mentha spp) and grape seed extract (Handiadka et al., 2012b). A number of possible mechanisms for the reported anti-CINV actions of these plants have been proposed. These include inhibition of 5$\mathrm{HT}_{3}$ receptor, substance $\mathrm{P}$ and NK1 receptors, antioxidant and free radical scavenging activity, antiinflammatory actions, chemo and radio-protective effects, immunomodulation, neuromodulation, antispasmodic effects, and regulation of gastrointestinal motility. Since these TMs may contain multiple bioactive compounds it appears likely that multiple mechanisms are involved (Handiadka et al., 2012b, Suzuki et al., 2013).

Previous reviews have reported that multi-ingredient TMs combined with chemotherapy could reduce CINV in various cancers (Dong et al., 2010; Li and Ling, 2012; Ohnishi and Takeda, 2015; Liu et al., 2008). In advanced CRC, a meta-analysis of RCT results showed FOLFOX4 combined with TMs produced a $10.3 \%$ reduction in grade $3 / 4$ nausea and vomiting compared to FOLFOX4 alone (Chen et $a l ., 2014)$. However, numerous TMs were used in these studies so it remains unclear whether any particular plant ingredients were responsible for the reported effects.

The aims of this review and meta-analysis are to assess whether integrative management of CRC, in which TMs are added to oxaliplatin regimens, reduced the incidence of CINV and whether any particular TMs showed promise for further research into their anti-emetic and/or nausea alleviating effects.

\section{Method}


PubMed, EMBASE, Cochrane CENTRAL, CINAHL, Science Direct, PsycINFO, China Academic Journals (CNKI) and Chinese Science and Technology Journals (CQVIP) were searched from their respective inceptions for RCTs that combined an oxaliplatin regimen with TM for the treatment of participants who had been diagnosed with CRC based on pathology tests and measured CINV as an outcome. There was no restriction on participant age or gender, inpatient or outpatient, or route of administration of the TM, or concurrent use of anti-emetic drugs. The terms used for PubMed and a list of journals that were hand-searched are provided in Supp 1.

Review methods were based on Cochrane Handbook 5.1.0 (Higgins and Green, 2011). Data were extracted independently by MC \& IZ who also assessed Risk of Bias, with mediation by AZ or BM. Meta-analysis was conducted using Review Manager (RevMan) 5.1 as Risk Ratio (RR) with 95\% confidence interval $(95 \% \mathrm{CI})$ fixed effect model. Heterogeneity was measured using $\mathrm{I}^{2}$. Risk difference (RD) was used as a measure of absolute difference. Publication bias was assessed using a funnel plot (Higgins and Green, 2011). Studies with zero events were included to avoid overestimation of effect (Fiedrich et al., 2007). The following subgroup and sensitivity analyses were planned: 1. route of TM administration; and 2.composition of the multi-ingredient orally administered TMs.

The approach to analyzing the subgroups of TM interventions that contained the same ingredients (mainly plants) was based on the method described in (Chen et al., 2015). The rationale for this approach was that many of the multi-ingredient TM interventions used different combinations of the same plants. Therefore, by investigating the pooled effects of multiple studies that employed the same plant, it may be possible to identify which plants contributed to the observed effects on CINV. In addition, it may also be possible to identify specific combinations of plants that showed the greatest contributions to CINV alleviation. Briefly, the approach involved a multi-level procedure. At level 1, all studies that employed the same plant were treated as a sub-group and the pooled $\mathrm{RR}(95 \% \mathrm{CI})$ and $\mathrm{I}^{2}$ for CINV were calculated. This was done for all plants that appeared in two or more studies. The results were listed in ascending order and significant results were noted. When the sub-group showed no significant effect on CINV and/or there was important heterogeneity in the pooled result $\left(\mathrm{I}^{2}\right.$ greater than $30 \%$ ), the plant was eliminated from further consideration. At level two, subgroups of studies that employed the same two plants in the TM interventions were identified and the RRs were calculated for each pool. At level three, combinations of three plants were considered and so on until there were no possible combinations that showed significant effects. This approach produced a matrix of pooled RRs for multiple sub-groups of studies.

The following five criteria were applied to the matrix of results to identify plants and combinations of plants that showed promise for further research into their effects on CINV. 1. the RR of the sub-group of studies that employed the plant was significantly lower than the control; 2 . the RR was equal or lower than the RR for all the orally administered multi-ingredient TM interventions; 3 . no important heterogeneity ( $\mathrm{I}^{2}$ below $\left.30 \%\right)$; and 4: the RR results for the plant were significant at multiple levels of combination; 5 . the plant was not always combined with another particular plant, therefore it was possible to assess the independent contribution of that plant.

\section{Results}

Following screening of the 2,648 citations derived from database searches and the 54 studies from print journal searches, 88 full-text studies were evaluated. Finally, 30 studies were included in the review. Three studies did not provide data suitable for pooling (Chen et al. 2005; Deng and Shen, 2010; Liang et al., 2009), so 27 studies, published from 2005 to 2013, that enrolled 1,843 
(T:960/C:883) assessable participants were included in the meta-analyses (Figure 1). Six studies employed commercially available injections and 21 studies used orally administered TMs. All studies used the WHO system or the National Cancer Institute Common Toxicity Criteria (NCI-CTC). These systems are comparable and divide nausea and vomiting into 4 grades (Miller et al., 1981; National Cancer Institute, 1999). Study characteristics are presented in Table 1.

\section{Methodological assessment}

Thirteen studies (48.1\%) were judged as 'low' risk of bias for sequence generation (Table 1). One study was blinded, used a placebo control for the TM and described allocation concealment (Kono et al., 2013). The other studies were judged as 'high risk' for blinding of outcome assessment since nausea is a subjective outcome which is usually recorded by participants and personnel so results could have been influenced by lack of blinding. Two studies were judged as 'high risk' for incomplete outcome data since reasons for dropouts were not given and 'intent to treat' was not used (Li et al., 2007; Zhang et al., 2010). Studies with no dropouts were judged as 'low risk'. Studies were judged as 'low risk' of selective outcome reporting when there was a published protocol and results for all outcome measures were reported. Studies with no protocol were judged as 'unclear'. The Funnel Plots suggest risk of publication bias was low for the oral administration group (Figure Supp 1).

\section{Meta-analysis of reduction of nausea and vomiting}

Meta-analysis was conducted for all grades of nausea and vomiting combined. When RR is less than +1 and RD is less than zero (IV model, fixed, 95\% CI), it favors the test group. A lower RR indicates a lower risk of nausea and vomiting.

\section{$\underline{\text { Total group }}$}

For all 27 studies, the test groups showed significantly reduced nausea and vomiting (RR 0.65 [0.59, $0.71], \mathrm{I}^{2}=28 \%$ )(Figure 2$)$. The absolute risk reduction was $24 \%$ compared to controls $(\mathrm{RD}=-0.24[-$ $0.28,-0.19], \mathrm{I}^{2}=48 \%$ ). In the 17 studies that stated anti-emetic drugs, such as ondansetron or granisetron, were used in both groups the RR was $0.68[0.60,0.77], \mathrm{I}^{2}=32 \%$ whereas in the studies that did not mention use of anti-emetic drugs $(n=10)$ the RR was $0.60[0.51,0.70], I^{2}=19 \%$.

Injection group

Four different injection products were tested in 6 studies (Table 1). There was a significant reduction in nausea and vomiting ( $\mathrm{RR} 0.73[0.61,0.86], \mathrm{I}^{2}=60 \%, \mathrm{RD}=-0.20[-0.29,-0.12], \mathrm{I}^{2}=50 \%$ ) in the TM plus oxaliplatin groups. The heterogeneity was moderate to substantial (Figure 2). Co-kushen Injection ( $\mathrm{n}=2$ ) (Ding et al., 2010; Tao and $\mathrm{Xu}, 2013$ ) showed significantly reduced nausea and vomiting ( $\mathrm{RR} 0.66[0.50,0.86], \mathrm{I}^{2}=64 \%$ ) but there was substantial heterogeneity. Kang'ai Injection $(\mathrm{n}=2)$ (Qiu 2011; Yang, 2008) showed a significant reduction with no important heterogeneity (RR $\left.0.47[0.29,0.77], \mathrm{I}^{2}=28 \%\right)$.

Oral administration group

The TMs were administered orally as decoctions, capsules or tablets in 21 studies. The combination of TMs plus oxaliplatin showed a significant reduction in nausea and vomiting incidence compared to the same oxaliplatin regimens (RR $0.62[0.55,0.69], \mathrm{I}^{2}=5 \%$ ). The absolute risk reduction was $25 \%$ (RD $-0.25[-0.30,-0.20], \mathrm{I}^{2}=49 \%$ )(Figure 2).

Effects of individual plant-based ingredients in orally administered TMs 
The orally administered TMs contained 98 different plant-based ingredients with an average of 12 ingredients per TM intervention. The 48 plants that were used in two or more studies were included in the following sub-group analyses. Thirty of these plants showed significant RRs for reduction of incidence of CINV with low heterogeneity $\left(\mathrm{I}^{2}<30 \%\right)$. The effects of these plants were also assessed when they appeared as pairs, triplets and higher level combinations in the TM interventions.

Significant RR results with low heterogeneity that were equal or lower than the total pool for the oral interventions RR $0.62[0.55,0.69]$ are reported in Table 2 and Table Supp 1. The full botanical name and Chinese name in pin yin of each plant is given when it is first mentioned in the text.

Subsequently, the name is shortened to genus only.

The following plants were the most frequently used in the TM interventions: Poria cocos (Schw) Wolf (fu ling)(n=16); Atractylodes macrocephala Koidz. (bai zhu) $(\mathrm{n}=16)$; Coix lacryma-jobi L. (yi ren) $(\mathrm{n}=14)$; Astragalus membranaceus (Fisch.) Bge. (huang qi) $(\mathrm{n}=13)$, and Codonopsis pilosula (Franch.). Nannf. (dang shen) ( $\mathrm{n}=12)$.

$\underline{\text { Level 1: Single plants }}$

Of the 30 plants included at the level 1 analysis (Table 2), most were always associated with another particular plant in the TM interventions so it was not possible to determine if they made an independent contribution to the RR result. However, the following seven plants did not always appear in association with another particular plant. Of these, Panax ginseng C. A. Mey. (ren shen) $(n=4)$ had the lowest RR $\left(0.51[0.39,0.66], \mathrm{I}^{2}=0 \%\right)$, followed by Poria $(\mathrm{n}=16)\left(\mathrm{RR} 0.61[0.54,0.69], \mathrm{I}^{2}=15 \%\right)$, Coix (n=14) (RR 0.61 [0.53, 0.70], $\left.\mathrm{I}^{2}=29 \%\right)$, Codonopsis ( $\left.=12\right)\left(\mathrm{RR} 0.61[0.52,0.72], \mathrm{I}^{2}=28 \%\right)$, Panax notoginseng (Burk.) F.H. Chen (tian qi) $(\mathrm{n}=4)\left(\mathrm{RR} 0.61[0.43,0.87], \mathrm{I}^{2}=0 \%\right)$, Atractylodes $(\mathrm{n}=16)\left(\mathrm{RR} 0.62[0.54,0.71], \mathrm{I}^{2}=13 \%\right)$, and Astragalus $(\mathrm{n}=13)\left(\mathrm{RR} 0.65[0.55,0.76], \mathrm{I}^{2}=0 \%\right)$.

\section{Level 2: Pairs of plants}

Seven pairs of plants showed RRs that were lower than the total pool (Table Supp1). The lowest RRs were for Panax G. + Astragalus $(\mathrm{n}=4)\left(\mathrm{RR} 0.49[0.35,0.67], \mathrm{I}^{2}=0 \%\right)$ followed by Poria + Dioscorea opposita Thunb.(shan yao)(n=5)(RR $\left.0.56[0.47,0.67], \mathrm{I}^{2}=0 \%\right)$.

Level 3: Combinations of three plants

Six different triplets showed significant RRs that were lower than the total pool. The combination of Dioscorea+Coix+Poria $(n=3)$ had the lowest RR $\left(0.49[0.37,0.65], \mathrm{I}^{2}=0 \%\right)$, followed by Panax $\mathrm{G}$ + Atractylodes + Coix $(\mathrm{n}=3)\left(\mathrm{RR} 0.52[0.39,0.69], \mathrm{I}^{2}=0 \%\right)$.

\section{Level 4: Combinations of four plants}

Atractylodes + Poria + Coix + Glycyrrhiza uralensis Fisch (gan cao) was the only combination that was significant and lower or equal to the pool (RR $0.51[0.38,0.70], \mathrm{I}^{2}=0 \%, \mathrm{n}=3$ ).

Level 5: Combinations of five plants

Three combinations of five plants showed RRs lower than the total pool. Astragalus+Atractylodes + Coix + Lycium barbarum L. (gou qi zi) + Scutellaria barbata D. Don. (ban zhi lian)(n=3) had the lowest RR (0.58 [0.41, 0.83], $\left.\mathrm{I}^{2}=0 \%\right)$.

Level 6: Combinations of six plants 
Six combinations of six plants showed significant RRs lower than the total pool. The lowest RR $(0.50$ $\left.[0.36,0.69], \mathrm{I}^{2}=0 \%\right)$ was for Panax G+ Dioscorea + Coix + Glycyrrhiza + Atractylodes + Poria $(n=2)$.

\section{Level 7: Combinations of seven plants}

One combination of seven plants was lower than the total pool: Codonopsis + Atractylodes + Astragalus + Coix + Poria + Crataegus pinnatifida Bge (shan zha) + Hordeum vulgare L. (mai ya) $(\mathrm{n}=2)$ (RR $0.47[0.33,0.68], \mathrm{I}^{2}=0 \%$ ).

\section{TMs with consistent results at multiple levels}

Six plants showed significantly reduced RRs that were lower than or equal to the pool with low heterogeneity at multiple levels. Atractylodes, Poria and Coix appeared at all seven levels when used as components of various TM interventions. Glycyrrhiza appeared at five levels while Astragalus and Panax G appeared at four levels.

\section{Discussion}

The meta-analysis showed reduction in CINV in both the injection and oral groups but there was substantial heterogeneity in the injection group $\left(\mathrm{I}^{2}=60 \%\right)$ compared to the oral group $\left(\mathrm{I}^{2}=5 \%\right)$. In the oral intervention studies the absolute risk reduction was $25 \%$ which was higher than for the injection group (20\%). In a previous meta-analysis of tumour response rate, the injection groups appeared more effective than the oral groups (Chen et al., 2015). One likely reason for these differences is the injection products are mainly aimed at aiding tumour response rather than reducing CINV. Nevertheless, the result for the two studies of Kang'ai injection, which is composed of Panax G, Astragalus and Sophora flavescens Ait., showed significant reduction in CINV incidence without important heterogeneity $\left(I^{2}=28 \%\right)$.

It has been suggested that combining certain TMs with anti-emetics results in greater benefit (Dong, 2012). In the total group, there was a slightly reduced benefit in the 17 studies that used anti-emetic drugs compared to the ten that did not. However, it is possible that some studies did not report the use of anti-emesis medications since these are in routine use. Therefore this result is difficult to interpret. This issue warrants further investigation.

The following six plants appeared at multiple levels of combination in the oral interventions: Atractylodes ( $\mathrm{n}=16)$, Poria $(\mathrm{n}=16)$, Coix $(\mathrm{n}=14)$, Astragalus $(\mathrm{n}=13)$, Glycyrrhiza $(\mathrm{n}=5)$, and Panax $\mathrm{G}$ $(\mathrm{n}=4)$. This list contains the plants with the highest overall frequencies, such as Atractylodes and Poria, and also some lower frequency plants such as Glycyrrhiza and Panax G. Conversely, some relatively frequent plants such as Curcuma $(n=7)$ did not show an elevated RR. Therefore, the selection process did not simply reflect overall frequency within the data set.

Ginger was not included in the final analyses, although it appeared to significantly reduce CINV (RR $0.43[0.31,0.61])$, since it was used in only two studies and the heterogeneity was substantial $\left(\mathrm{I}^{2}=69 \%\right)$. A number of other plants used traditionally for nausea were also excluded for the same reasons. It is important to note that the plants selected above are not the only plants that showed improved RR for CINV when they were included in a TM intervention, what they showed was consistent effects in multiple studies and in multiple combinations. Another caveat on the interpretation of these results is that the short-listed herbs cannot be ranked in order of effectiveness since each RR was based on a different sub-group of studies. 
Based on the information in the clinical trial reports it was not possible to determine whether the short-listed plants were included in order to reduce CINV or for other reasons. This issue is made more complex since plants are considered to have multiple effects in traditional medicine. However, all are traditionally used for treating gastrointestinal disorders including nausea, bloating, fatigue, poor appetite, and diarrhoea (Bensky et al., 2004).

The effects of extracts and compounds derived from the six plants identified as potentially reducing CINV have received research attention in experimental models in animals and cell-lines to assess their effects on emesis, pica, gastrointestinal motility and gastro-protection. The volume of published research is variable with Ginseng, Atractylodes, and Poria having received the most attention. This research is reviewed for each of the six plants below.

\section{Panax ginseng}

The anti-emetic effect of Korean red ginseng total extract (KRGE) on nausea and vomiting was investigated in ferrets administered intraperitoneal cisplatin $(7.5 \mathrm{mg} / \mathrm{kg}$ ) which induced both nausea and vomiting with one-hour latency. The animals were monitored very 30 mins and the total number of episodes of nausea and vomiting were marked. Pre-treatment with orally administered KRGE one hour and two hours before cisplatin significantly attenuated the cisplatin-induced nausea and vomiting in a dose-dependent manner. No significant effect was evident when KRGE was administered 4 hours prior to cisplatin (Kim et al., 2005).

In rodents, emetics do not produce vomiting but instead induce pica - the eating of kaolin. In rats, the effects of an extract of Korean ginseng (KG) administered before and after cisplatin, on pica, food intake, body weight, haematological parameters and histopathology was investigated by Raghavendran et al (2011). Pre-treatment with KG one hour before cisplatin significantly reduced kaolin intake at 24, 48, and 72 hours post-cisplatin. Normal food intake significantly improved compared to the group that received cisplatin alone and there was less reduction in body weight. Posttreatment KG showed similar effects. The increases in the levels of white blood cells, neutrophils, lymphocytes induced by cisplatin were significantly lower in the rats pre-treated with $\mathrm{KG}$, suggesting that KG reduced cisplatin-induced inflammation. Cisplatin-induced damage to the gastric mucosa and small intestine was reduced by pre-treatment, but not by post-treatment, with KG (Raghavendran et al., 2011). A similar result was obtained using American ginseng berry extract (AGBE) and ginsenoside Re which is one of its constituents. Pre-treatment reduced cisplatin-induced pica and improved food intake. When tested for antioxidant actions, both AGBE and ginsenoside Re were found to scavenge superoxide and hydroxyl radicals (Mehendale et al., 2005).

Pre-treatment with ginsenoside $\mathrm{Rg} 2$ has been reported to have an inhibitory effect on human 5- $\mathrm{HT}_{3 \mathrm{~A}}$ receptors expressed in Xenopus oocytes that was dose dependent and reversible (Choi et al., 2003). Using the same model, similar effects have been reported for two ginsenoside metabolites (Lee et al., 2004). These studies suggest that the reported effects of ginseng on nausea and vomiting may be via antagonism of the $5-\mathrm{HT}_{3 \mathrm{~A}}$ receptor.

Poria cocos

Tai et al investigated the effects of a range of triterpenes extracted from Poria in frogs orally administered copper sulphate as an emetic. The latency to first emesis was significantly prolonged compared to controls by some, but not all, triterpenes. Those showing a significant anti-emetic effect had an exo-methylene group at C24 in their side chain (Tai et al., 1995). 
The effects of three Poria-derived triterpenoids [PA: Pachymic acid; DA: dehydroeburicoic acid; HA: 3 $\beta$-hydroxylanosta-7,9(11), 24-trien-21-oic acid] on human 5- $\mathrm{HT}_{3 \mathrm{~A}}$ receptors was investigated in Xenopus oocytes using a two electrode voltage-clamp technique. Each triterpenoid showed concentration dependent, reversible inhibition on 5HT-induced inward current with HA showing the highest potency (Lee et al., 2009).

\section{Atractylodes macrocephala}

The effects of an extract of Atractylodes on restitution of the intestinal mucosa after damage, was investigated in a cell migration model using intestinal epithelial (IEC-6) cells treated with Atractylodes extract, spermidine (SPD, $5 \mu \mathrm{mol} / \mathrm{L}$ ) as the positive control, the polyamine inhibitor alpha-difluoromethylornithine (DFMO, $2.5 \mathrm{mmol} / \mathrm{L}$ ) as the negative control, and a no treatment control. At doses of $100 \mathrm{mg} / \mathrm{L}$ and $200 \mathrm{mg} / \mathrm{L}$, Atractylodes significantly increased IEC- 6 cell migration after wounding compared to no treatment and the effect was comparable to that of SPD. The effect of Atractylodes was retained when combined with DFMO. Atractylodes exposure increased cellular polyamine content and other markers indicating a polyamine dependent mechanism (Song et al., 2015). In human gastric mucosa epithelium, Atractylodes extract promoted the growth of human gastric mucosa cells, DNA synthesis and pepsin secretion, but had no effect on acid secretion (Zhu et al., 2003).

Atractylodes has been reported to enhance gastric emptying and small intestinal motility in mice fed Atractylodes extract plus the marker Blue dextran 2000, compared to a saline control (Li et al., 1996). This prokinetic effect could be blocked by atropine in a study of isolated mouse ileum which indicated the effect may be mediated via muscarinic receptors (Ma et al., 1996).In guinea pig colon sections, Atractylodes extract was reported to increase smooth muscle contraction (Ding et al., 2005).

\section{Astragalus membranaceus}

A number of studies have investigated the effect of Astragalus on gastrointestinal motility. In healthy dogs, the investigators measured the myoelectric activity in the duodenum and jejunum after $25 \%$ concentrated solution $(1 \mathrm{ml} / \mathrm{kg}$ ) Astragalus extract was injected into the dog's empty stomach. The duration of each myoelectric cycle, each phase of the cycleand the electrical potential were measured. The results showed Astragalus could significantly extend the duration of myoeletric cycles in the duodenum and jejunum but the motility enhancing effect was most pronounced in the jejunum (Yang et al., 1993). In normal mice, Astragalus significantly enhanced small intestine motility and antagonized the inhibitive effects of atropine and the non-selective beta-adrenergic agonistisoproterenol. In the stomach, Astragalus also antagonized inhibition of gastric emptying induced by atropine $(3 \mathrm{mg} / \mathrm{kg})$, but did not antagonize the dopamine-serotonin receptor antagonist metoclopramide $(0.8 \mathrm{mg} / \mathrm{kg})$ (Zheng et al., 2003).

In healthy humans, small intestine transmission time was measured by using a hydrogen breath test to determine the peak value of lactose absorption after taking $18 \mathrm{~g}$ lactose orally. After taking Astragalus for one week, the time to the peak value of lactose absorption was significantly shortened, compared to before administration of Astragalus, suggesting increased motility (Qiao et al., 2001).

\section{Glycyrrhiza (Licorice)}

The effects of aqueous extracts of several TMs, including Glycyrrhiza, Astragalus and Atractylodes, were tested in isolated smooth muscle strips taken from different gastric regions of the rat. Glycyrrhiza, Astragalus, and Atractylodes increased longitudinal and circular fundic muscle tension; 
Glycyrrhiza and Atractylodes enhanced longitudinal muscle tension in strips from the gastric body; while Glycyrrhiza increased the motility index of pyloric circular muscle (Zheng et al., 1998).

A study that investigated the effects of isoliquiritigenin (a flavonoid in Glycyrrhiza spp.) on gastrointestinal motility in mice fed a charcoal meal, found an inhibitory effect at low doses $(0.003$, $0.03 \mathrm{mg} / \mathrm{kg}$ ) and a prokinetic effect at high doses $(3$ and $30 \mathrm{mg} / \mathrm{kg}$ ). Subsequent in-vitro studies indicated that the spasmogenic effect involved activation of muscarinic receptors, while the spasmolytic effect was associated with blockade of calcium channels (Chen et al., 2009).

Sato et al investigated the effect of glycycoumarin, a compound from Glycyrrhiza, on carbamylcholine (CCh)-induced contraction of mouse jejunum and reported an antispasmodic effect related to the inhibition of the phosphodiesterase 3 pathway (Sato et al., 2006).

Coix

The effect of de-hulled Coix seed was examined in an indomethacin-induced gastric lesion model in rats. Erosion of the gastric mucosa was examined by imaging and by histopathological observation. Coix extract was found to produce dose-dependent gastroprotection against indomethacin. This effect was at least partially due antioxidant actions of the phenolic acids in Coix (Chung et al 2011). A methanol extract of Coix seeds was found to reduce nitric oxide and superoxide production in RAW 264.7 macrophages (Seo et al 2000).

\section{Safety of the TM interventions}

The included studies did not report any serious adverse events associated with TMs and the metaanalyses results did not show increased CINV in any of the studies. Also, when combined with antiemetic drugs the TMs did not appear to reduce their effectiveness, rather, the results were suggestive of enhanced effect. In an analysis of the effects of TMs on tumour response in CRC, the use of TMs was not associated with any reduction in the efficacy of the oxaliplatin-based chemotherapy (Chen et $a l ., 2015)$. The six plants identified by the sensitivity analyses are all in common use in traditional medicine (Bensky et al., 2004).

\section{Conclusions}

In nausea and vomiting associated with oxaliplatin based chemotherapy for CRC, the addition of TMs appears to significantly reduce incidence based on a meta-analysis of 27 studies. This effect was most pronounced in the group of 21 studies that administered the TMs orally. There was low statistical heterogeneity in this group, the oxaliplatin regiments and CINV measurements were consistent across studies and there was considerable similarity in the TMs used but the lack of blinding in most studies may have led to overestimation of the effects on CINV. Further sensitivity analysis of the TMs based on their ingredients, identified six plants that were associated with significant reductions in CINV without important heterogeneity in the meta-analysis results. Experimental studies of these six plants have reported inhibitory effects on nausea and vomiting (or its animal equivalent), regulation of gastrointestinal motility, gastro-protective effects, and/or antioxidant actions which may at least partially explain the effects identified in the meta-analyses of the clinical trial results. These plants warrant further clinical research as additions to chemotherapy regimens in patients whose CINV is not sufficiently well-controlled by conventional therapies. 


\section{Figure legends}

Figure 1. Flow diagram of the search and selection process of RCTs of Oxaliplatin regimens combined with traditional medicine (TM) for colorectal cancer (CRC) with incidence of nausea and vomiting as an outcome

CT: clinical trial of TM without randomisation; DU: duplicate publication; MT: multi-cancer CT; RE: review; Other: not a controlled trial, not a CT of TM.

Figure 2: Forest plot of the effects of traditional medicine (TM) interventions on CINV incidence in colorectal cancer (CRC) treated with oxaliplatin regimens

Figure Supp. 1: Funnel plot of CINV outcomes of 27 studies of TMs for CRC: oral and non-oral groups

RR: risk ratio of $\mathrm{CINV}$

\section{References}

Bensky D, Clavey S, Stoger E eds. 2004.Chinese Herbal Medicine: Materia Medica, Revised 3 Edition. Seattle, WA: Eastland Press.

Chen G, Zhu L, Liu Y, Zhou Q, Chen H, Yang J. 2009. Isoliquiritigenin, a flavonoid from licorice, plays a dual role in regulating gastrointestinal motility in vitro and in vivo. Phytother Res23:498-506.

Chen M, May BH, Zhou IW, Xue CC, Zhang AL. 2014. FOLFOX 4 combined with herbal medicine for advanced colorectal cancer: a systematic review. Phytother Res.28:976-991.

Chen M, May BH, Zhou IW, Xue CC, Zhang AL. 2015. Meta-analysis of oxaliplatin-based chemotherapy combined with traditional medicines for colorectal cancer: contributions of specific plants to tumor response. Integr Cancer Ther. doi: 10.1177/1534735415596424

Chen X, Liang Q, Li XY, Zhang Y, Li JW, Liang Z. 2005. Effect of composite salviae dripping pill combined with chemotherapy in patients with colorectal carcinoma. Chin J. of Surg of Integr Trad and West Med.11:300-303.

Choi S, Lee JH, Oh S, Rhim H, Lee SM, Nah SY. 2003. Effects of ginsenoside Rg2 on the 5-HT3A receptor-mediated ion current in Xenopus oocytes. Mol Cells.15:108-113.

Chung PC, Hsia SM, Lee MY, Chen HJ, Cheng F, Chan LC, Kuo YH, Lin YL, Chiang W. 2011. Gastroprotective Activities of Adlay (Coix lachryma-jobi L. var. ma-yuen Stapf) on the Growth of the Stomach Cancer AGS Cell Line and Indomethacin-Induced Gastric Ulcers. J. Agric. Food Chem. 59, 6025-6033. doi.org/10.1021/jf2009556

Deng DH, Shen XH. 2010. Clinical oservation of Yiqixiaoji decoction combined with chemotherapy treatement on 18 cases of advanced colorectal cancer. Fujian J Trad Chin Med.41:13-14.

Ding SQ, Ding YJ, Guo R, et al. 2005. Effect of atractylodes rhizome on locomotion of colon smooth muscle in guinea pig. Chin J Integr Trad West Med Dig.13:100-102.

Ding X, Xiao XY, Yang XY, Zhu BH. 2010. Clinical observation of compound Kushen injection combined with FOLFOX4 regime for patients with advanced colorectal cancer. China Oncology.20:860-863. 
Dong J, Su SY, Wang MY, Zhan Z.2010. Shenqi fuzheng, an injection concocted from Chinese medicinal herbs, combined with platinum-based chemotherapy for advanced non-small cell lung cancer: a systematic review. J Exp Clin Cancer Res.;29:137.

Dong W. 2012. New pill of Frutus combination 5-HT3 receptor antagonists chemotherapy treating clinical observation of nausea and vomiting [Master], Shandong University of Traditional Chinese Medicine.

Fang MZ, Li M. 2008. The curative effect of the treatment for metastatic colorectal cancer by the FOLFOX4 scheme combining Javanica oil emulsion and the observation of adverse effects. Chin J Inform on Trad Chin Med.15:74-75.

Friedrich JO, Adhikari NK, Beyene J.2007. Inclusion of zero total event trials in meta-analyses maintains analytic consistency and incorporates all available data. BMC Med Res Methodol.7:16.

Haniadka R, Rajeev AG, Palatty PL, Arora R, Baliga MS. 2012a. Zingiber officinale (ginger) as an anti-emetic in cancer chemotherapy: a review. J Altern Complement Med.18:440-444.

Haniadka R, Popouri S, Palatty PL, Arora R, Baliga MS. 2012b. Medicinal plants as antiemetics in the treatment of cancer: a review. Integr Cancer Ther.11:18-28.

Higgins JPT, Green S, (editors). 2011. Cochrane Handbook for Systematic Reviews of Interventions Version 5.1.0 [updated March 2011]. The Cochrane Collaboration: www.cochranehandbook.org.

Hu AM, Chuan Y, Li Z. 2006. The clinical efficacy of chemotherapy combined with Chinese traditional drugs for advanced colonrectal cancer patients. The Pract J Cancer.21:74-76.

Kim JH, Yoon IS, Lee BH, et al. 2005. Effects of Korean red ginseng extract on cisplatin-induced nausea and vomiting. Arch Pharm Res. 28:680-684.

Kono T, Hata T, Morita S, et al. 2013. Goshajinkigan oxaliplatin neurotoxicity evaluation (GONE): a phase 2, multicenter, randomized, doubleblind, placebocontrolled trial of goshajinkigan to prevent oxaliplatininduced neuropathy. Cancer chemotherapy and pharmacology. 72:1283-1290.

Kono T, Mishima H, Shimada M, Morita S, Sakamoto J. 2009. Preventive effect of goshajinkigan on peripheral neurotoxicity of FOLFOX therapy: a placebo-controlled double-blind randomized phase II study (the GONE Study). Jpn J Clin Oncol. 39:847-849.

Lao GQ, Chen F, He XH, et al. 2012. Clinical research on treating advanced colorectal cancer with the Jianpi Jiedu decoction plus chemotherapy. Clin J Chin Med.4:1-3.

Lee BH, Jeong SM, Lee JH, et al. 2004. Differential effect of ginsenoside metabolites on the 5-HT3A receptor-mediated ion current in Xenopus oocytes. Mol Cells. 29:51-56.

Lee JH, Lee YJ, Shin JK, et al. 2009. Effects of triterpenoids from Poria cocos Wolf on the serotonin type 3A receptor-mediated ion current in Xenopus oocytes. Eur J Pharmacol. 615:27-32.

Li HJ, Dong L, Fu SY, Li Y. 2007. Comparative study on treatment of advanced colorectal cancer by Aidi injection combined with FOLFOX4 regimen and by FOLFOX4 regimen alone. Chin $J$ Integr Trad and West Med. 27:1086-1089.

Li XQ, Ling CQ. 2012. Chinese herbal medicine for side effects of transarterial chemoembolization in liver cancer patients: a systematic review and meta-analysis. J Chin Integr Med.10:1341-1362.

Li Y, Sun XY, Zhu Z. 1996. Influence of Astragalus membranaceus on gastric empting and small intestinal motility in mice. Med J Liaoning.10:186.

Li YJ, Chen JZ, Huang WX, Li XF.2007. Treatment of Wenshen Jianpi Fang combination with chemotherapy for advanced colorectal cancer Fujian J Trad Chin Med. 38:13-14.

Liang QL, Pan DC, Xie JR. 2009. Effect of Shenqi Fuzheng injection combined with chemotherapy in treating advanced colorectal carcinoma. Chin J Integr Trad and West Med.29:439-441.

Lim MH, Zhu DZ. 2012. Pien Tze Huang combined with chemotherapy in treatment of advanced colon cancer Fujian J Trad Chin Med. 43:8-9.

Liu H, Sun MF. 2009. Clinical abservation of kang'ai fangyi tablet combined with chemotherapy in treating advanced colorectal cancer. Chin J Inform Trad Chin Med.16:2.

Liu J, Wang WP, Zhou Y. 2005.Observation on therapeutic effect of jianpi huoxue herbs combined with chemotherapy in treating post-operational colonic cancer patients.Chin J integr med. 25:207-209. 
Liu WY, Liu QY, Liu HW, Guan BS, Li Z, Wang X. 2011. Clinical study of Combination of Chinese traditional and Western Medicine for 16 advanced colorectal cancer Jilin J Trad Chin Med.31:984-985.

Liu X, Xu F, Wang G, Diao X, Li Y. 2008. Kanglaite injection plus chemotherapy versus chemotherapy alone for non-small cell lung cancer patients: A systematic review and metaanalysis. Curr Ther Res Clin Exp.69:381-411.

Lohr L. 2008. Chemotherapy-induced nausea and vomiting. Cancer J. 14:85-93.

Ma J, Wang GH, Cai DF, Fan Y, Gu XX. 2005. Clinical observation of Jianpi Xiaoliu decoction in preventing postoperative colorectal carcinoma recurrence and metastasis. Shanghai J Trad Chin Med. 39:24-25.

Ma XS, Fan XP, Chen Z, Li CW, Xing SS. 1996. Effects and mechanism of Rhizoma Atractylodes macrocephalae on gastrointestinal motility in animals.Chin J Digest.16:261-264.

Marx WM, Teleni L, McCarthy AL, et al. 2013. Ginger (Zingiber officinale) and chemotherapyinduced nausea and vomiting: a systematic literature review. Nutr Rev. 71:245-254.

Mehendale S, Aung H, Wang A, et al. 2005. American ginseng berry extract and ginsenoside Re attenuate cisplatin-induced kaolin intake in rats. Cancer chemoth pharm.56:63-69.

Miller AB, Hoogstraten B, Staquet M, Winkler A. 1981. Reporting results of cancer treatment. Cancer. 47:207-214.

National Cancer Institute. Common Toxicity Criteria. 1999. Version 2.0 National Cancer Institute.

Navari RM. 2009. Pharmacological management of chemotherapy-induced nausea and vomiting: focus on recent developments. Drugs. 69:515-533.

NCCN Clinical Practice Guidelines in Oncology, v 1. 2012: Antiemesis. National Comprehensive Cancer Network (NCCN) [online]. Available from URL: http://www.nccn.org/professionals/physician_gls/PDF/antiemesis.pdf. Accessed 05 Jul. 2015

Ohnishi S, Takeda H. 2015. Herbal medicines for the treatment of cancer chemotherapy-induced side effects. Front Pharmacol.6:14.

Qiao YF, Jiang FH, Kong BJ. 2001. Effect of Radix Astragalus on the transmission small Intestine in health subjects. Trad Chin Drug Res \& Clin Pharm.12:204-205+235.

Qiu ZC. 2011. Kang'ai Injection combined with chemotherapy in treating advanced colorectal cancer. Shaanxi J Trad Chin Med.32:3-4.

Raghavendran HR, Rekha S, Shin JW, et al. 2011. Effects of Korean ginseng root extract on cisplatininduced emesis in a rat-pica model. Food Chem Toxicol. 49:215-221.

Sato Y, Akao T, He JX, et al. 2006. Glycycoumarin from Glycyrrhizae Radix acts as a potent antispasmodic through inhibition of phosphodiesterase 3. J Ethnopharmacol. 105:409-414.

Seo WG, Pae HO, Chai KY, Yun YG, Kwon TH, Chung HT. 2000. Inhibitory effects of methanol extract of seeds of Job's Tears (Coix lachryma-jobi L. var. ma-yuen) on nitric oxide and superoxide production in RAW 264.7 macrophages. Immunopharmacol Immunotoxicol. 22:545554.

Song HP, Li RL, Zhou C, Cai X, Huang HY. 2015. Atractylodes macrocephala Koidz stimulates intestinal epithelial cell migration through a polyamine dependent mechanism. $J$ Ethnopharmacol. 159:23-35.

Song WX, Zhang WW. 2012. Clinical study of combination of Xiaoliuhuaji Decoction II and chemotherapy on the treatment of advanced colorectal cancer. Jiangxie J Trad Chin Med. 44:1314.

Suzuki H, Asakawa A, Amitani H, Fujitsuka N, Nakamura N, Inui A. 2013. Cancer cachexia pathophysiology and translational aspect of herbal medicine. Jpn J Clin Oncol. 43:695-705.

Tai T, Akita Y, Kinoshita K, Koyama K, Takahashi K, Watanabe K. 1995. Anti-emetic principles of Poria cocos. Planta Med. 61:527-530.

Tao CL, Xu JF. 2013. Co-Kushen injection combined with chemotherapy in treatment of advanced coloreactal cancer Guid J Trad Chin Med Pharm. 19:42-44.

Wang H. 2008. The observation on efficacy of Yiqi Huoxue Buchang decoction with chemotherapy in patients with rectal cancer of postoperation. J Liaoning Univer Trad Chin Med.10:81-82.

Wang JZ, Ke YH, Liu PC, Wu CY, Chen HB. 2011 Yichangning decoction combined with FOLFOX4 in treatmen of advanced colorectal cancer. Fujian J Trad Chin Med.42:23-24. 
Wu G, Yu G, Li J, Xiong F. 2010 Short term therapeutic effect on treatment of postoperational large intestine carcinoma by Fupiyiwei decoction combined with chemotherapy and it's effect on immune function. Chin J Chin materia medica. 35:782-785.

$\mathrm{Xu}$ YX, Wang SL. 2010 Clinical oservation of jiangniling combined with chemotherapy treatment on advanced colorectal cancer Chin Med Herald. 7:329-330.

Yang DZ, Bi QH, Ding AL, Ying CZ. 1993 The effect of Astragalus membranaceus on small intestine myoelectric activity $J$ Chin Integr Med. 13:616-617+582.

Yang YF. The comparative study of Kang'ai injection combined with FOLFOX4 regimen for advanced colorectal cancer. 2008. Fuzhou, Fujian University of Traditional Chinese Medicine.

Yang ZY, Liu C, Luo J, L. X. 2005 Clinical study of integrated chinese herbal medicine with chemitherapy on post- operational stage III colorectal cancer patients. Chin J Clin Onc Rehab.12:190-192.

Zhang HT, Fang CT, Huang ZY, Liu LW. 2008 Clinical observation of integrated Chinese medicine and chemotherapy on 31 cases of advanced colon cancer. J New Chin Med.40:22-23.

Zhang Q, Wang XM, Yang GW. 2010 Clinical research of Guben Xiaoliu Capsule combined with FOLFOX4 plan for treatment of advanced colorectal cancer. Beijing J Trad Chin Med.14:255257.

Zhang Q, Zhao WS, Yu J, Wang X. 2006 Clinical study on advanced colorectal cancer treated by Yiqi Huoxue TCM combined with chemotherapy. Chin J Inform Trad Chin Med.13:17-18.

Zhang WW, Song WX. 2013 Clinical study of combination of Xiaoliuhuaji Decoction I and chemotherapy on the treatment of postoperative colorectal cancer. Hebei J Trad Chin Med.35:69-71.

Zhang Y, Xu J, Sun J. 2010 Clinical study of Jianpi Jiedu decoction plus FOLFOX4 regimen in the treatment of advanced colorectal cancer. Glob Trad Chin Med.3:117-120.

Zheng TZ, Li W, Ding YH, Wei YL, Qu SY. 2003 Effects of Huangqi on gastrointestinal motility of mice in vivo. Pharm Clin Chin Materia Medica.19:25-26.

Zheng TZ, Li W, Qu SY, He DY, Ding YH, Wei YL. 1998 Action of traditional Chinese medicine of buqi on contractile activity of isolated gastric muscle strops in rats. $J$ Lanzhou Med Coll.24:5-7.

Zhu JQ, Zhang KH, Huang DQ, Chen J, Xie Y, Wang CW. 2003 The experiment study of effect of large bighead Atractylodes on human gastric mucosa cells function Chin J Endosc.9:21-23.

Zou B, He L, Song H, Xin S. 2007 Gubenkang'ai decoction combined with chemotherapyin treating advanced colorectal cancer. Liaoning J Trad Chin Med. 34:773-774. 


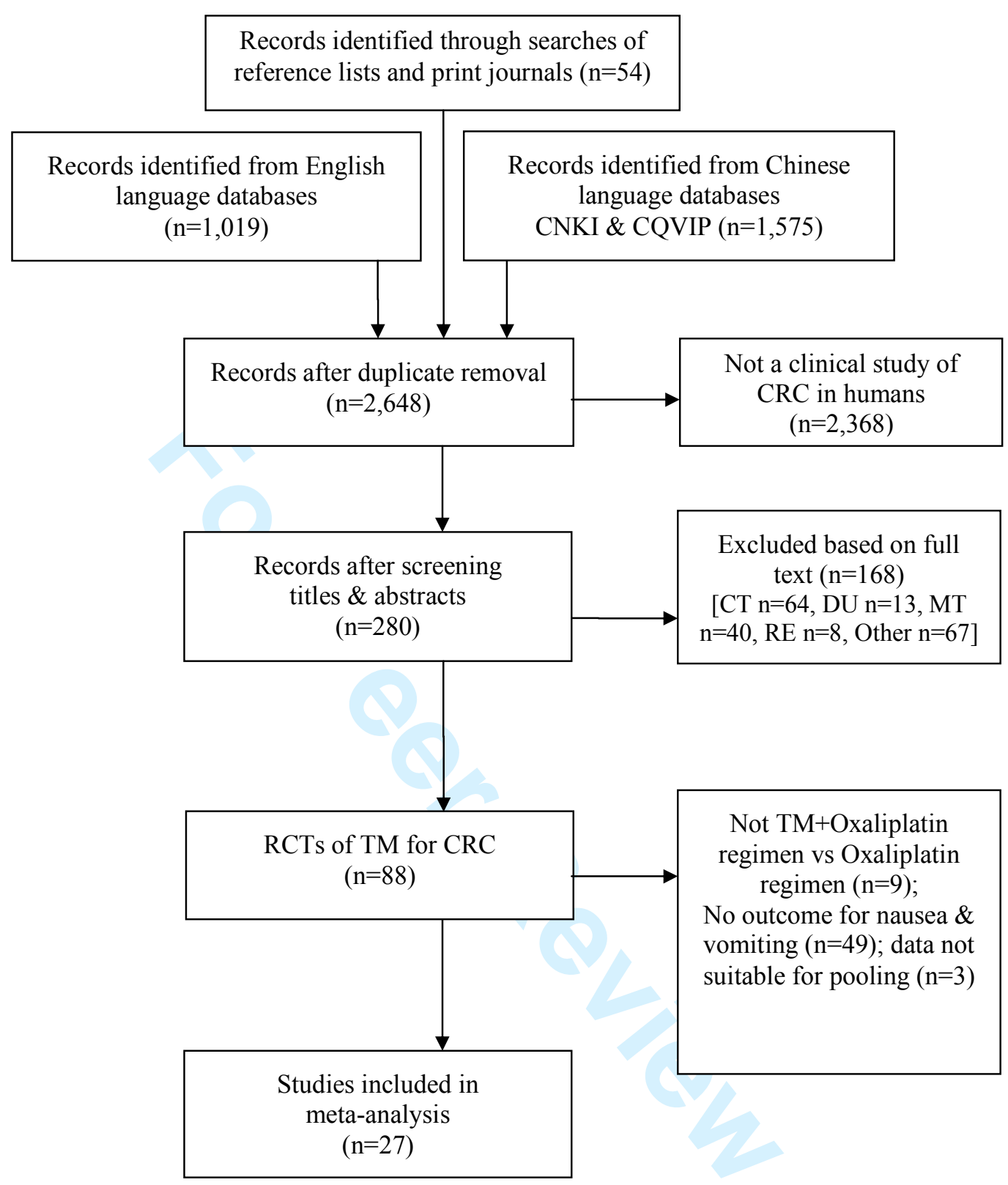

Figure 1. Flow diagram of the search and selection process of RCTs of Oxaliplatin regimens combined with traditional medicine (TM) for colorectal cancer (CRC) with incidence of nausea and vomiting as an outcome

CT: clinical trial of TM without randomisation; DU: duplicate publication; MT: multi-cancer CT; RE: review; Other: not a controlled trial, not a CT of TM. 
Risk Ratio IV, Fixed, $95 \% \mathrm{Cl}$

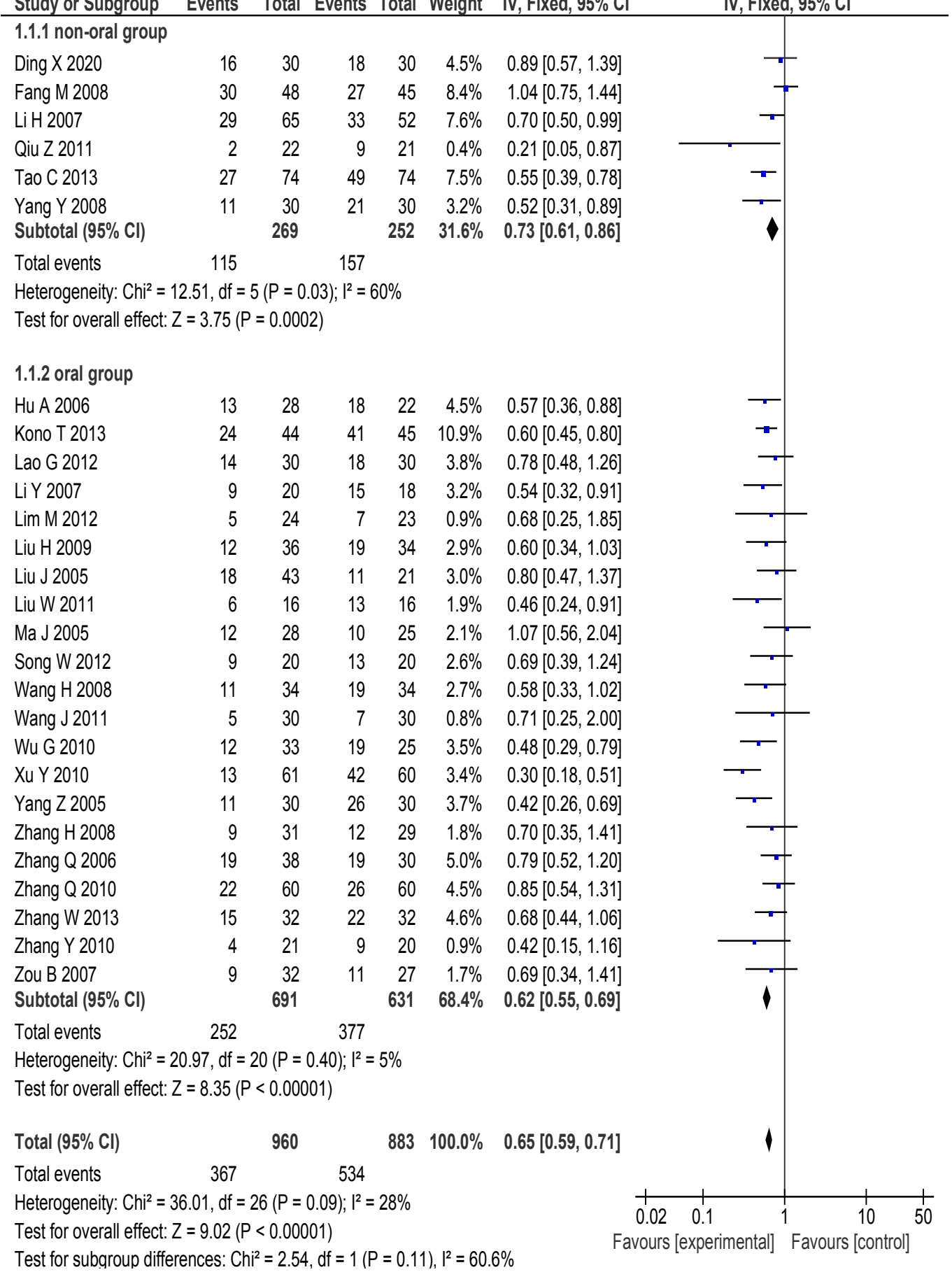

Figure 2: Forest plot of the effects of traditional medicine (TM) interventions on CINV incidence in colorectal cancer $(\mathrm{CRC})$ treated with oxaliplatin regimens 
Table 1: Characteristics of randomised controlled trials of traditional medicines (TM) combined with oxaliplatin-based regimens for colorectal cancer (CRC) with nausea and vomiting incidence as an outcome

\begin{tabular}{|c|c|c|c|c|}
\hline $\begin{array}{l}\text { First } \\
\text { author } \\
\text { (year). }\end{array}$ & $\begin{array}{l}\text { Sample size } \\
\text { T/C; Gender } \\
\text { (M) T/C; Age } \\
\text { T/C }\end{array}$ & $\begin{array}{l}\text { TM Intervention; dosage } \& \\
\text { duration }\end{array}$ & $\begin{array}{l}\text { Oxaliplatin regimen; dose, cycles }(\mathrm{T} / \mathrm{C}) \text {; } \\
\text { anti-emetic drug. }\end{array}$ & $\begin{array}{l}\text { Risk of bias (SG, AC, BPt, } \\
\text { BOA, IOD, SOR) }\end{array}$ \\
\hline $\begin{array}{l}\text { Fang M } \\
(2008)\end{array}$ & $\begin{array}{l}48 / 45 ; 30 / 28 \\
59.5 \pm 11.3 / 56.4 \\
\pm 10.3\end{array}$ & $\begin{array}{l}\text { Javanica oil emulsion injection; } 30 \\
\text { ml, ID, day } 1-14 \text { / cycles, for two } \\
\text { cycles }\end{array}$ & $\begin{array}{l}\text { FOLFOX 4: } 2 \text { cycles (all); anti-emetic } \\
\text { drug used (unknown) }\end{array}$ & $\begin{array}{l}\text { SG: L, AC: U, BPt: H, BOA } \\
\text { (subj): H, IOD: L, SOR: U. }\end{array}$ \\
\hline $\begin{array}{l}\mathrm{Hu} \mathrm{A} \\
(2006) .\end{array}$ & $\begin{array}{l}28 / 22 ; 18 / 14 ; \\
49.3 \pm 4.5 / 48.5 \pm 4 \\
.3\end{array}$ & $\begin{array}{l}\text { Treatment with } 4 \text { different TM } \\
\text { decoctions according to symptom } \\
\text { differentiation; one decoction per } \\
\text { day, for more than } 30 \text { days. }\end{array}$ & $\begin{array}{l}\text { FOLFOX: Ox. } 130 \mathrm{mg} / \mathrm{m}^{2}, \mathrm{ID} \text {, day } 1, \mathrm{LV} \\
200 \mathrm{mg} / \mathrm{m}^{2} \text {, ID, day } 1-2,5-\mathrm{FU} 2400 \mathrm{mg} \\
/ \mathrm{m}^{2}, \mathrm{ID}, 46 \text { hours, cycle/21 days, } 2 / 2 \\
\text { cycles; Granisetron, Metoclopramide. }\end{array}$ & $\begin{array}{l}\text { SG: U, AC: U, BPt: H, BOA } \\
\text { (obj): L, IOD: L, SOR: U. }\end{array}$ \\
\hline $\begin{array}{l}\text { Kono T } \\
(2013) \text {. }\end{array}$ & $\begin{array}{l}\text { 27/23; NS; } \\
67 / 61 \text { (mean) }\end{array}$ & $\begin{array}{l}\text { TJ-107 Goshajinkigan aqueous } \\
\text { extract; or placebo was } \\
\text { administered orally, tid, before each } \\
\text { meal ( } 7.5 \mathrm{~g} / \text { day) for } 26 \mathrm{wks}\end{array}$ & $\begin{array}{l}\text { FOLFOX } 4 \text {, or mFOLFOX6: Ox. } 85 \\
\mathrm{mg} / \mathrm{m}^{2}, \mathrm{ID} \text {, day } 1 \text {, LV } 200 \mathrm{mg} / \mathrm{m}^{2}, \mathrm{ID}, 5- \\
\text { FU } 400 \mathrm{mg} \text { bolus, follow } 2400 \mathrm{mg} / \mathrm{m}^{2} \text {, ID } \\
\text { for } 46 \text { hours, } 14 \text { days/cycle, } 8 / 8 \text { cycles or } \\
\text { more. }\end{array}$ & $\begin{array}{l}\text { SG: L, AC: L, BPt: L, BOA } \\
\text { (obj): L, IOD: L, SOR: L. }\end{array}$ \\
\hline $\begin{array}{l}\text { Lao G } \\
(2012)\end{array}$ & $\begin{array}{l}30 / 30 ; 21 / 23 \\
35.1 \pm 20.2 / 36.7 \pm \\
20.1\end{array}$ & $\begin{array}{l}\text { Jianpijiedu decoction; one } \\
\text { decoction per day, } 21 \text { days /cycle, } \\
\text { for two cycles. }\end{array}$ & $\begin{array}{l}\text { FOLFOX: Ox. } 130 \mathrm{mg} / \mathrm{m}^{2}, \mathrm{ID} \text {, day } 1, \mathrm{LV} \\
200 \mathrm{mg} / \mathrm{m}^{2}, \mathrm{ID} \text {, day } 1,5-\mathrm{FU} 500 \mathrm{mg} \text { bolus } \\
\text { day } 1,2400 \mathrm{mg} / \mathrm{m}^{2}, \mathrm{ID}, 48 \text { hours, day } 1-2 \text {, } \\
21 \text { days } / \text { cycle, } 2 / 2 \text { cycles; } 5 \text {-HT3 receptor } \\
\text { antagonist and dexamethasone. }\end{array}$ & $\begin{array}{l}\text { SG: L, AC: U, BPt: H, BOA } \\
\text { (obj): L, IOD: L, SOR: U. }\end{array}$ \\
\hline $\begin{array}{l}\mathrm{Li} \mathrm{H} \\
(2007)\end{array}$ & $\begin{array}{l}\text { 65/52; 43/36; } \\
\text { 58/59 (med.) }\end{array}$ & $\begin{array}{l}\text { Aidi injection; } 60 \mathrm{ml}, \mathrm{ID} \text {, day } 1-10 \text {, } \\
14 \text { days/cycle, for } 11 \mathrm{wks} \text {. }\end{array}$ & $\begin{array}{l}\text { FOLFOX 4: } 5.5 / 5.5 \text { cycles (mean); } \\
\text { Granisetron. }\end{array}$ & $\begin{array}{l}\text { SG: U, AC: U, BPt: H, BOA } \\
\text { (obj): L, IOD: L, SOR: U. }\end{array}$ \\
\hline $\begin{array}{l}\mathrm{Li} \mathrm{Y} \\
(2007) .\end{array}$ & $\begin{array}{l}20 / 18 ; 22 \text { (all); } \\
72.2 \text { (med. all) }\end{array}$ & $\begin{array}{l}\text { Wenshenjianpi decoction; one } \\
\text { decoction per day, for med. 10-12 } \\
\text { wks. }\end{array}$ & FOLFOX 4: 6/5.5 cycles (med.). & $\begin{array}{l}\text { SG: L, AC: U, BPt: H, BOA } \\
\text { (obj): L, IOD: H, SOR: U. }\end{array}$ \\
\hline
\end{tabular}




\begin{tabular}{|c|c|c|c|c|}
\hline $\begin{array}{l}\text { Lim M } \\
(2012) .\end{array}$ & $\begin{array}{l}\text { 24/23; } 17 / 14 \\
56.89 \pm 14.77 / 55 \\
37 \pm 16.01\end{array}$ & $\begin{array}{l}\text { Pianzaihuang capsule; two } \\
\text { capsules, bid; } 14 \text { days/cycle, } 8-10 \\
\text { cycles. }\end{array}$ & FOLFOX4; 8-10/8-10 cycles. & $\begin{array}{l}\text { SG: U, AC: U, BPt: H, BOA } \\
\text { (obj): L, IOD: L, SOR: U. }\end{array}$ \\
\hline $\begin{array}{l}\text { Liu H } \\
\text { (2009). }\end{array}$ & $\begin{array}{l}36 / 34 ; 16 / 18 \\
50.2 \text { (mean) }\end{array}$ & $\begin{array}{l}\text { Kang'ai fangyi pian; one decoction } \\
\text { per day, } 21 \text { days / cycle, for } 3 \\
\text { cycles. }\end{array}$ & $\begin{array}{l}\text { FOLFOX: Ox. } 130 \mathrm{mg} / \mathrm{m}^{2} \text {, ID, day } 1, \mathrm{LV} \\
200 \mathrm{mg} / \mathrm{m}^{2}, \mathrm{ID} \text {, day } 1-5,5-\mathrm{FU} 300 \mathrm{mg} \\
/ \mathrm{m}^{2}, \mathrm{ID} \text {, day } 1-5,21 \text { days } / \text { cycle, } 3 / 3 \\
\text { cycles. }\end{array}$ & $\begin{array}{l}\text { SG: L, AC: U, BPt: H, BOA } \\
\text { (obj): L, IOD: L, SOR: U. }\end{array}$ \\
\hline $\begin{array}{l}\text { Liu J } \\
(2005) .\end{array}$ & $\begin{array}{l}43 / 21 ; 23 / 10 \\
61.52 \pm 10.12 \\
/ 60.11 \pm 9.78\end{array}$ & $\begin{array}{l}\text { Jianpihuoxue formulae; one } \\
\text { decoction per day, } 30 \text { days/ cycle, } 3 \\
\text { cycles. }\end{array}$ & $\begin{array}{l}\text { FOLFOX; Ox. } 150 \mathrm{mg} / \mathrm{m}^{2}, \mathrm{ID} \text {, day } 1, \mathrm{LV} \\
200 \mathrm{mg} / \mathrm{m}^{2}, \mathrm{ID} \text {, day } 1-5,5 \text {-FU } 500 \mathrm{mg} \\
/ \mathrm{m}^{2}, \mathrm{ID} \text {, day } 1-5,30 \text { days } / \text { cycle, } 3 / 3 \\
\text { cycles; Ondansetron hydrochloride. }\end{array}$ & $\begin{array}{l}\text { SG: L, AC: U, BPt: H, BOA } \\
\text { (obj): L, IOD: L, SOR: U. }\end{array}$ \\
\hline $\begin{array}{l}\text { Liu W } \\
\text { (2011). }\end{array}$ & $\begin{array}{l}\text { 16/16; } 11 / 10 ; \\
51 / 52(\text { mean })\end{array}$ & $\begin{array}{l}\text { Yi er kang capsule; } 4-6 \text { capsules, } \\
\text { bid, for } 5-25 \text { months. }\end{array}$ & $\begin{array}{l}\text { FOLFOX: Ox. } 130 \mathrm{mg} / \mathrm{m}^{2}, \text { ID, day } 1, \mathrm{LV} \\
100 \mathrm{mg} / \mathrm{m}^{2}, \mathrm{ID} \text {, day } 1-5,5-\mathrm{FU} 400 \mathrm{mg} \\
/ \mathrm{m}^{2}, \mathrm{ID} \text {, day } 1-5,21 \text { days } / \text { cycle, } 6 / 6 \\
\text { cycles; Ondansetron. }\end{array}$ & $\begin{array}{l}\text { SG: U, AC: U, BPt: H, BOA } \\
\text { (obj): L, IOD: L, SOR: U. }\end{array}$ \\
\hline $\begin{array}{l}\text { Ma J } \\
(2005) .\end{array}$ & $\begin{array}{l}\text { 28/25; } 15 / 13 ; \\
58.1 / 57.5(\text { mean })\end{array}$ & $\begin{array}{l}\text { Jianpixiaoliu decoction; one } \\
\text { decoction per day, } 90 \text { days/ cycle, } 2 \\
\text { cycles. }\end{array}$ & $\begin{array}{l}\text { FOLFOX: Ox. } 130 \mathrm{mg} / \mathrm{m}^{2}, \text { ID, day } 1, \mathrm{LV} \\
200 \mathrm{mg} / \mathrm{m}^{2}, \mathrm{ID} \text {, day } 1-5,5-\mathrm{FU} 375 \mathrm{mg} \\
/ \mathrm{m}^{2}, \mathrm{ID} \text {, day } 1-5,21 \text { days } / \text { cycle, } 6 / 6 \\
\text { cycles. }\end{array}$ & $\begin{array}{l}\text { SG: U, AC: U, BPt: H, BOA } \\
\text { (obj): L, IOD: L, SOR: U. }\end{array}$ \\
\hline $\begin{array}{l}\text { Qiu Z } \\
(2011) .\end{array}$ & $\begin{array}{l}\text { 22/21; 14/13; } \\
56.9 / 52.7 \text { (med.) }\end{array}$ & $\begin{array}{l}\text { Kang'ai injection; } 40 \mathrm{ml} \text {, ID, day } \\
1-10,14 \text { days/ cycle, for } 4 \text { cycles. }\end{array}$ & FOLFOX4, 4/4 cycles. & $\begin{array}{l}\text { SG: U, AC: U, BPt: H, BOA } \\
\text { (obj): L, IOD: L, SOR: U. }\end{array}$ \\
\hline $\begin{array}{l}\text { Song W } \\
(2012) \text {. }\end{array}$ & $\begin{array}{l}20 / 20 ; 12 / 13 \\
56.4 \pm 9.1 \\
/ 48.3 \pm 8.2\end{array}$ & $\begin{array}{l}\text { Xiaoliuhuajichangfang II; one } \\
\text { decoction per day, } 21 \text { days/ cycle, } 2 \\
\text { cycles. }\end{array}$ & $\begin{array}{l}\text { FOLFOX: Ox. } 135 \mathrm{mg} / \mathrm{m}^{2}, \mathrm{ID} \text {, day } 1, \mathrm{LV} \\
200 \mathrm{mg} / \mathrm{m}^{2}, \mathrm{ID} \text {, day } 1-2,5 \text {-FU } 2400 \mathrm{mg} \\
/ \mathrm{m}^{2}, \mathrm{ID} \text {, for } 48 \text { hours, } 21 \text { days/ cycle, } 2 / 2 \\
\text { cycles; Ramosetron, Metoclopramide. }\end{array}$ & $\begin{array}{l}\text { SG: L, AC: U, BPt: H, BOA } \\
\text { (obj): L, IOD: L, SOR: U. }\end{array}$ \\
\hline $\begin{array}{l}\text { Tao C } \\
\text { (2013). }\end{array}$ & $\begin{array}{l}74 / 74 ; 51 / 50 \\
60.1+7.9 \\
/ 60.4+8.9\end{array}$ & $\begin{array}{l}\text { Co-kushen injection; } 15 \mathrm{ml} \text { per day, } \\
\text { ID, started } 14 \text { days before } \\
\text { chemotherapy, } 5 \text { wks/cycle, for } 1 \\
\text { cycle. }\end{array}$ & $\begin{array}{l}\text { FOLFOX: Ox. } 135 \mathrm{mg} / \mathrm{m}^{2}, \text { ID, day } 1, \mathrm{LV} \\
200 \mathrm{mg} / \mathrm{m}^{2}, \mathrm{ID}, 2 \text { hours, day } 1-5,5-\mathrm{FU} \\
500 \mathrm{mg} / \mathrm{m}^{2}, \mathrm{ID}, 8-10 \text { hours, day } 1-5, \\
3 \text { wks/cycle, } 1 / 1 \text { cycle. }\end{array}$ & $\begin{array}{l}\text { SG: U, AC: U, BPt: H, BOA } \\
\text { (obj): L, IOD: L, SOR: U. }\end{array}$ \\
\hline $\begin{array}{l}\text { Wang H } \\
\text { (2008). }\end{array}$ & $\begin{array}{l}34 / 34 ; 20 / 22 \\
52.58 \pm 8.12 / 51.1 \\
1 \pm 7.72\end{array}$ & $\begin{array}{l}\text { Yiqiguoxiebuchang decoction; one } \\
\text { decoction per day, for } 3 \text { mths. }\end{array}$ & $\begin{array}{l}\text { FOLFOX: Ox. } 85 \mathrm{mg} / \mathrm{m}^{2}, \text { ID, day } 1, \mathrm{LV} \\
\text { 200mg/m², ID, day } 1-2,5-\mathrm{FU} 500 \mathrm{mg} \\
\text { bolus day } 1,5-\mathrm{FU} 2500 \mathrm{mg} / \mathrm{m}^{2}, \mathrm{ID} \text {, for } 48 \\
\text { hours, } 21 \text { days/ cycle, } 4 / 4 \mathrm{cycles} \text {; } \\
\text { Ondansetron hydrochloride. }\end{array}$ & $\begin{array}{l}\text { SG: U, AC: U, BPt: H BOA } \\
\text { (obj): L, IOD: L, SOR: U. }\end{array}$ \\
\hline Wang J & $30 / 30 ; 18 / 21 ;$ & Yichangning decoction; one & FOLFOX4, 21 days /cycle, $2 / 2$ cycles; & SG: L, AC: U, BPt: H, BOA \\
\hline
\end{tabular}




\begin{tabular}{|c|c|c|c|c|}
\hline$(2011)$. & $\begin{array}{l}52.3 \pm 6.2 / \\
56.7 \pm 7.8\end{array}$ & decoction per day, for $2 \mathrm{mths}$. & Ondansetron. & (obj): L, IOD: L, SOR: U. \\
\hline $\begin{array}{l}\text { Wu G } \\
(2010) \text {. }\end{array}$ & $\begin{array}{l}33 / 25 ; 23 / 17 \\
55.4 \pm 13.6 / 52.8 \\
\pm 15.2\end{array}$ & $\begin{array}{l}\text { Fupiyiwei decoction; one decoction } \\
\text { per day, for } 24 \text { wks. }\end{array}$ & $\begin{array}{l}\text { FOLFOX 4: 12/12 cycles; Ondansetron } \\
\text { hydrochloride }\end{array}$ & $\begin{array}{l}\text { SG: L, AC: U, BPt: H, BOA } \\
\text { (obj): L, IOD: L, SOR: U. }\end{array}$ \\
\hline $\begin{array}{l}\mathrm{Xu} \mathrm{Y} \\
(2010)\end{array}$ & $\begin{array}{l}61 / 60 ; 38 / 37 \\
53 / 52(\text { mean })\end{array}$ & $\begin{array}{l}\text { Jiangniling formulae; one decoction } \\
\text { per day, } 14 \text { days/cycle, for } 8-10 \\
\text { cycles }\end{array}$ & $\begin{array}{l}\text { FOLFOX 4: 11.1/7.8 (mean) cycles; } \\
\text { Granisetron. }\end{array}$ & $\begin{array}{l}\text { SG: U, AC: U, BPt: H, BOA } \\
\text { (subj): H, IOD: L, SOR: U. }\end{array}$ \\
\hline $\begin{array}{l}\text { Yang Y } \\
(2008) \text {. }\end{array}$ & $\begin{array}{l}30 / 30 ; 16 / 19 \\
51.07+10.44 \\
151.33+10.95\end{array}$ & $\begin{array}{l}\text { Kang'ai injection; } 50 \mathrm{ml} \text {, ID, day1- } \\
\text { 20, 30days/cycle, for } 2 \text { cycles. }\end{array}$ & FOLFOX4, 4/4 cycles; Granisetron. & $\begin{array}{l}\text { SG: U, AC: U, BPt: H, BOA } \\
\text { (obj): L, IOD: L, SOR: U. }\end{array}$ \\
\hline $\begin{array}{l}\text { Yang Z } \\
(2005)\end{array}$ & $\begin{array}{l}30 / 30 ; 18 / 20 \\
29-70 / 28-69\end{array}$ & $\begin{array}{l}\text { Xuesaitong injection, } 500 \mathrm{mg}, \mathrm{ID} ; \\
\text { Huangqi injection, } 60 \mathrm{ml}, \mathrm{ID} ; \\
\text { Shenmai injection, } 50 \mathrm{ml} \text {, ID \&TM } \\
\text { decoction, one decoction per day, } \\
\text { day1-5, } 21 \text { days/ cycle, for } 2 \text { cycles. }\end{array}$ & $\begin{array}{l}\text { FOLFOX: Ox. } 200 \mathrm{mg} / \mathrm{m}^{2}, \text { ID, day } 1, \mathrm{LV} \\
200 \mathrm{mg} / \mathrm{m}^{2}, \mathrm{ID} \text {, day } 1-5,5-\mathrm{FU} 500 \mathrm{mg} \\
/ \mathrm{m}^{2}, \text { ID day } 1-5,2 / 2 \text { cycles. }\end{array}$ & $\begin{array}{l}\text { SG: U, AC: U, BPt: H, BOA } \\
\text { (subj): H, IOD: L, SOR: U. }\end{array}$ \\
\hline $\begin{array}{l}\text { Zhang H } \\
\text { (2008) }\end{array}$ & $\begin{array}{l}31 / 29 ; 28 / 23 \\
52.35 / 53.4(\text { mea } \\
\text { n) }\end{array}$ & $\begin{array}{l}3 \text { TM decoctions based on } \\
\text { symptom differentiation; one } \\
\text { decoction per day. Started one } \\
\text { week before chemotherapy till one } \\
\text { week after chemotherapy } \\
\text { completed. }\end{array}$ & $\begin{array}{l}\text { FOLFOX 4: } 4 / 4 \text { cycles; Ondansetron } \\
\text { hydrochloride. }\end{array}$ & $\begin{array}{l}\text { SG: U, AC: U, BPt: H, BOA } \\
\text { (subj): H, IOD: L, SOR: U. }\end{array}$ \\
\hline $\begin{array}{l}\text { Zhang Q } \\
\text { (2006). }\end{array}$ & $\begin{array}{l}\text { 38/30; 35(all); } \\
54.8(\text { mean all })\end{array}$ & $\begin{array}{l}\text { Yiqihuoxue formulae; one } \\
\text { decoction per day, } 21 \text { days/ cycle, } \\
\text { for } 3 \text { cycles. }\end{array}$ & $\begin{array}{l}\text { FOLFOX: Ox.125 mg/m } / \mathrm{m}^{2} \text { ID, day } 1, \mathrm{LV} \\
\text { 200mg } / \mathrm{m}^{2}, \text { ID, day } 1-2,5 \text {-FU } 500 \mathrm{mg} / \mathrm{m}^{2} \\
\text { bolus, day } 1-2,2000 \mathrm{mg} / \mathrm{m}^{2} \text { ID for } 72 \\
\text { hours, } 21 \text { days } / \text { cycle, } 3 / 3 \text { cycles; } \\
\text { Ondansetron hydrochloride }\end{array}$ & $\begin{array}{l}\text { SG: L, AC: U, BPt: H, BOA } \\
\text { (obj): L, IOD: L, SOR: U. }\end{array}$ \\
\hline $\begin{array}{l}\text { Zhang Q } \\
\text { (2010). }\end{array}$ & $\begin{array}{l}60 / 60 ; 35 / 33 \\
56.2(\text { mean all); }\end{array}$ & $\begin{array}{l}\text { Gubenxiaoliu capsule; } 4 \text { capsules, } \\
\text { bid, for } 8 \text { wks. }\end{array}$ & $\begin{array}{l}\text { FOLFOX } 4,4 / 4 \text { cycles; Ondansetron } \\
\text { hydrochloride. }\end{array}$ & $\begin{array}{l}\text { SG: L, AC: U, BPt: H, BOA } \\
\text { (obj): L, IOD: L, SOR: U. }\end{array}$ \\
\hline $\begin{array}{l}\text { Zhang W } \\
\text { (2013). }\end{array}$ & $\begin{array}{l}32 / 32 ; 15 / 16 \\
56.8 \pm 10.1 / 46.4 \pm \\
9.2\end{array}$ & $\begin{array}{l}\text { Xiaoliuhuaji Decoction I; one } \\
\text { decoction per day, for } 5 \text { mths. }\end{array}$ & $\begin{array}{l}\text { FOLFOX: Ox. } 135 \mathrm{mg} / \mathrm{m}^{2}, \text { ID, day } 1, \mathrm{LV} \\
200 \mathrm{mg} / \mathrm{m}^{2}, \mathrm{ID} \text {, day } 1-2,5 \text {-FU } 2400 \mathrm{mg} \\
/ \mathrm{m}^{2}, \text { ID for } 48 \text { hours, } 21 \text { days/cycle, } 6 / 6 \\
\text { cycles; Ramosetron. }\end{array}$ & $\begin{array}{l}\text { SG: L, AC: U, BPt: H, BOA } \\
\text { (obj): L, IOD: L, SOR: U. }\end{array}$ \\
\hline $\begin{array}{l}\text { Zhang Y } \\
\text { (2010). }\end{array}$ & 21/20; NS; NS; & $\begin{array}{l}\text { Jianpijiedu decoction; one } \\
\text { decoction per day, for } 4 \text { wks. }\end{array}$ & FOLFOX 4: $2 / 2$ cycles. & $\begin{array}{l}\text { SG: U, AC: U, BPt: H, BOA } \\
\text { (obj): L, IOD: H, SOR: U. }\end{array}$ \\
\hline
\end{tabular}


FOLFOX: Ox.135 mg/m², ID, day 1, LV cycle, for 2 cycles(all); Granisetron,

T: treatment group, C: control group, M: male, N: number, NS: not stated, ID: intravenous drip, TM: Traditional medicine. 5-FU: 5-Fluorouracil; LV: Leucovorin; Ox.: Oxaliplatin; FOLFOX: Ox. + 5-FU + LV; bid: twice per day; tid: three times per day; qd: once per day; Wk: week; Mth: month; med.: median.

Risk of Bias Categories: SG: Sequence Generation, AC: Allocation Concealment, BPt: Blinding of Participants/Personnel, BOA (obj): Blinding of Outcome Assessment (subjective outcome measure i.e. nausea), IOD: Incomplete Outcome Data, SOR: Selective Outcome Reporting. Risk of Bias Judgements: L: low risk, U: $200 \mathrm{mg} / \mathrm{m}^{2}$, ID, day $1-2,5-\mathrm{FU} 2400 \mathrm{mg}$ $/ \mathrm{m}^{2}$, ID, for 48 hours, day 1, 21 days/ Metoclopramide. Unclear risk, H: High risk

SG: U, AC: U, BPt: $\mathrm{H}, \mathrm{BOA}$ (subj): H, IOD: L, SOR: U.

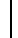


Table 2: Effects of specific TMs on CINV: Level 1 single TMs

\begin{tabular}{|c|c|c|c|c|}
\hline Traditional Medicine (species) & N studies & $\begin{array}{l}\mathbf{N} \\
\text { participants }\end{array}$ & RR $[95 \%$ CI $]$ & $\mathbf{I}^{2}$ \\
\hline Hordeum vulgare L. (mai ya) & 2 & 98 & $0.47[0.33,0.68]$ & 0 \\
\hline Crataegus pinnatifida Bge (shan zha) & 2 & 98 & $0.47[0.33,0.68]$ & 0 \\
\hline Massa medica fermentata (shen qu) & 2 & 120 & $0.47[0.30,0.73]$ & 0 \\
\hline Panax ginseng C. A. Mey. (ren shen)* & 4 & 222 & $0.51[0.39,0.66]$ & 0 \\
\hline Glycyrrhiza uralensis Fisch (gan cao)* & 3 & 170 & $0.51[0.38,0.70]$ & 0 \\
\hline Magnolia officinalis Rehd. et Wils (hou po) & 3 & 179 & $0.54[0.38,0.77]$ & 0 \\
\hline Amomum kravanh Pierre ex. Gagnep. (bai dou kou) & 2 & 117 & $0.54[0.36,0.81]$ & 0 \\
\hline Dioscorea opposita Thunb. (shan yao) & 5 & 321 & $0.56[0.47,0.67]$ & 0 \\
\hline Sophora flavescens Ait. (ku shen) & 2 & 92 & $0.56[0.35,0.92]$ & 0 \\
\hline Lycium barbarum L. (gou qi zi) & 3 & 168 & $0.58[0.41,0.83]$ & 0 \\
\hline Cornus officinalis Sieb. et Zucc. (shan zhu yu) & 2 & 139 & $0.59[0.46,0.75]$ & 0 \\
\hline Paeonia suffruticosa Andr. (mu dan pi) & 2 & 139 & $0.59[0.46,0.75]$ & 0 \\
\hline Alisma orientalis (Sam.) Juzep. (ze xie) & 2 & 139 & $0.59[0.46,0.75]$ & 0 \\
\hline Rehmannia glutinosa Libosch. (shu di huang) & 3 & 199 & $0.60[0.47,0.75]$ & 0 \\
\hline Nelumbo nucifera Gaertn. (lian zi) & 2 & 110 & $0.60[0.41,0.88]$ & 0 \\
\hline Poria cocos (Schw) Wolf (fu ling)* & 16 & 1012 & $0.61[0.54,0.69]$ & 15 \\
\hline Coix lacryma-jobi L. (yi ren)* & 14 & 945 & $0.61[0.53,0.70]$ & 29 \\
\hline Codonopsis pilosula (Franch.). Nannf. (dang shen) & 12 & 747 & $0.61[0.52,0.72]$ & 28 \\
\hline Paeonia lactiflora Pall. (bai shao) & 5 & 272 & $0.61[0.48,0.76]$ & 0 \\
\hline Panax notoginseng (Burk.) F.H. Chen (tian qi) & 4 & 245 & $0.61[0.43,0.87]$ & 0 \\
\hline Atractylodes macrocephala Koidz. (bai zhu)* & 16 & 976 & $0.62[0.54,0.71]$ & 13 \\
\hline Eclipta prostrata L. (mo han lian) & 2 & 129 & $0.63[0.41,0.97]$ & 0 \\
\hline Sophora japonica L. (huai hua) & 3 & 150 & $0.63[0.46,0.86]$ & 0 \\
\hline Scutellaria barbata D. Don. (ban zhi lian) & 6 & 356 & $0.64[0.50,0.81]$ & 0 \\
\hline
\end{tabular}

http://mc.manuscriptcentral.com/ptr 


\section{Page 23 of 23}

Phytotherapy Research

\begin{tabular}{|l|c|c|l|l|}
\hline Astragalus membranaceus (Fisch.) Bge. (huang qi)* & 13 & 733 & $0.65[0.55,0.76]$ & 0 \\
\hline Ligusticum chuanxiong Hort. (chuan xiong) & 2 & 114 & $0.65[0.46,0.92]$ & 0 \\
\hline Angelica sinensis (Oliv.) Diels. (dang gui) & 2 & 118 & $0.68[0.50,0.92]$ & 11 \\
\hline Hedyotis diffusa Willd. (she she cao) & 4 & 228 & $0.69[0.51,0.93]$ & 0 \\
\hline Akebia quinata (Thunb.) Decne. (ba yue zha) & 5 & 264 & $0.70[0.51,0.95]$ & 0 \\
\hline $\begin{array}{l}\text { Curcuma zedoaria (Berg.) Rosc. or C. phaeocaulis } \\
\text { Val. (e zhu) }\end{array}$ & 7 & 439 & $0.71[0.57,0.88]$ & 0 \\
\hline Spatholobus suberectus Dunn (ji xue teng) & 3 & 192 & $0.73[0.55,0.98]$ & 0 \\
\hline
\end{tabular}

*Included in the final six TMs 